\title{
Sending out an SOS
}

\section{An Obama gambit on space policy highlights the benefits and risks of turning to outside experts. David Goldston explains.}

W hen a public official appoints a commission to study a problem, it's usually assumed to be a craven strategy to delay a decision or to dodge responsibility. But sometimes tossing an issue over to outsiders actually offers the best chance of moving forward. That seems to be the case with the commission appointed in June by President Barack Obama's administration to review NASA's human spaceflight programme. Without such a panel, which is due to report late this month, developing a workable consensus on NASA's future would probably be impossible. The only problem is that reaching consensus might still be impossible even with the panel.

The panel, chaired by Norman Augustine, the widely respected former head of aerospace giant Lockheed Martin, is charged with figuring out how to put together a viable human spaceflight programme within the existing budget. No one thinks the United States has such a programme now. Both the budget and schedule for President George W. Bush's initiative for a US return to the Moon seem impossibly tight, and its spacecraft and rocket designs have always been controversial. Moreover, congressional supporters of the programme have never truly accepted the decision to cancel the space shuttle in 2010 and to abandon the International Space Station in 2016 to free up funds for the lunar project.

It didn't take Obama administration officials long to recognize that the status quo was unsustainable. Worse still, they realized, the budgetary and political instability in NASA's human spaceflight programme threatened their express commitments to rebuild the agency's Earth-science capabilities and to put its space-science programme, plagued by its own cost overruns, on a sound footing. But the administration had no clear path forward and little time. Shortly after taking office in January, it had to make decisions on budgets for fiscal years 2009 and 2010, not to mention an economic stimulus package.

The key officials handling the problem presidential science adviser John Holdren, acting NASA administrator Christopher Scolese, their staffs and the staff at the Office of Management and Budget - began to see a commission not only as the best way to move

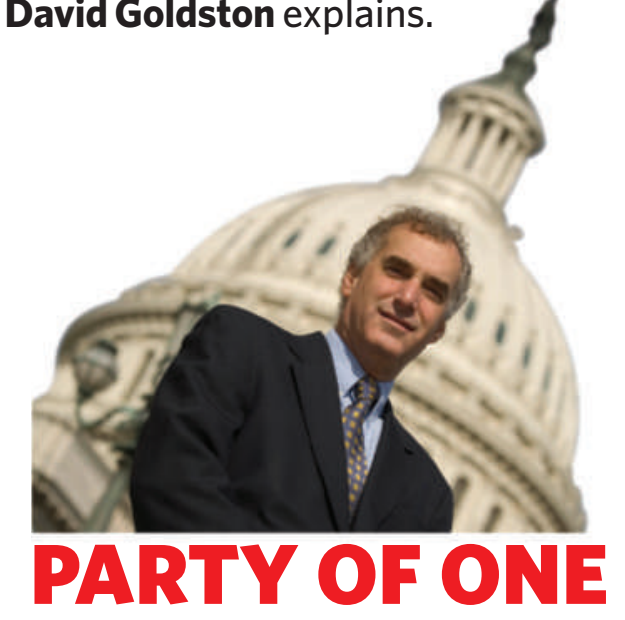

ahead, but as the sole way. They realized that the Obama administration on its own would never have the credibility to forge a new consensus with NASA's supporters. The administration would be too vulnerable to a range of disparate charges: that it was a captive of NASA, or not genuinely committed to space exploration, or merely interested in reversing Bush policy, or just trying to make the budget arithmetic work regardless of the consequences.

The administration did genuinely need the technical guidance a commission would provide - NASA couldn't be expected to objectively review its own work - but the primary motivation for appointing the Augustine panel was, legitimately, political. A respected group of experts with clout on Capitol Hill might be able to reshape the debate over NASA's future and tamp down the carping and second-guessing that had afflicted the human spaceflight programme and made its budget a perpetually open question.

A commission was good strategy within the White House as well. As a presidential candidate, Obama had eventually endorsed the lunar mission, but like most presidential hopefuls, space had hardly been his primary focus or interest. (Even President John F. Kennedy reportedly admitted to NASA officials, "I'm not that interested in space".) Yet Holdren and his colleagues realized that the nature of the space programme would have to be a presidential decision; fundamental policy choices with political and strategic consequences were involved. The Augustine panel, with its high-powered members and very public operation, would help get the president's attention. It would also give him more information on which to make a decision and confidence that all the options and angles had been reviewed. A commission was needed to gain credibility within the administration, not just outside it.

The only downside of such an approach was both basic and unavoidable: it wasn't clear what the panel would conclude. Turning to the commission, officials acknowledge, was something of a gamble, a 'crap shoot'.

If all goes well from the administration's point of view, the Augustine committee will design an exploration programme that can satisfy space enthusiasts while not veering far from its official charge to stay within the existing budget. Already everyone expects the group to offer several scenarios, with a number of them exceeding current spending targets. Panel members have talked seriously about extending both the space shuttle and station programmes, which each carry hefty price tags, and many experts believe the lunar programme needs significantly more cash to succeed.

If the higher-cost options are the only ones that win favour with human spaceflight advocates, the administration may be worse off than it would have been without the Augustine panel. Supporters of increased spending will have been given fresh ammunition and the enhanced legitimacy that the panel was supposed to provide the administration. If the costs are a lot higher, the president will be forced to reassess his commitment to returning to the Moon, his commitment to strengthen NASA's science programmes, or his effort to constrain the agency budget in a period of burgeoning deficits. The ploy will have backfired, opening a Pandora's box of fundamental questions the White House was quite reasonably trying to avoid.

The outcome of such a re-examination and the ensuing debate is difficult to predict. Spacepolicy issues have rarely been front-page news over the past 40 years, and even Bush's decision to return to the Moon faded quickly from public view and failed to generate much congressional discussion.

But a revised space policy now, at a time of high unemployment, soaring budget deficits and pent-up demands for scientific research, might lead to a more fully engaged debate about what NASA's priorities should be. The most likely result would be yet another armistice between NASA's human spaceflight and science programmes, leaving both insufficiently funded. For now, though, a genuine, broad and open conversation about NASA's focus remains space policy's final frontier. David Goldston (partyofonecolumn@gmail. com) is the director of government affairs at the Natural Resources Defense Council in Washington DC. Views expressed are his own. 